\title{
Gold deposits of Suriname: geological context, production and economic significance
}

\author{
Nicole M. E. Kioe-A-Sen ${ }^{1,2, *}$, Manfred J. van Bergen ${ }^{2}$, Theo E. Wong ${ }^{1}$ \\ \& Salomon B. Kroonenberg ${ }^{3}$
}

1 Department of Geology and Mining, Anton de Kom University of Suriname, Paramaribo, Suriname

2 Department of Earth Sciences, Utrecht University, Utrecht, The Netherlands

3 Delft University of Technology, Delft, The Netherlands

* Corresponding author. Email: nicole.kioe-a-sen@uvs.edu

Manuscript received: 21 June 2016, accepted: 17 September 2016

\section{Abstract}

Gold has been a major economic asset for Suriname for more than a century. The long history of gold mining, concentrated in large parts of a greenstone belt in the northeast of the country, began with small-scale artisanal extraction activities and has recently seen the development of major open-pit operations. Despite the range of mining activities, Suriname's gold deposits and occurrences are under-explored from a scientific point of view. Primary gold mineralisations in the greenstone belt occur in multiple forms, and although their origin is commonly related to the Palaeoproterozoic Trans-Amazonian orogeny, the controls of ore formation in specific cases often remain obscure. This contribution presents an abridged overview of currently available information on the geological setting and characteristics for some of the main deposits where gold is extracted. In view of the consistent link between gold metallogeny and granitoid-greenstone belts in the northern Guiana Shield, the mineralised settings in Suriname are discussed in a regional context.

Keywords: gold, mineral exploration, mining, Suriname

\section{Introduction}

Gold is currently one of the most important commodities for Suriname. Starting from the 1800 s this noble metal has always had a significant impact on the country's economy. Most of the gold deposits are located in the NW-SE-stretching Marowijne Greenstone Belt in the eastern part of Suriname (Fig. 1). They formed during the Palaeoproterozoic Trans-Amazonian orogeny following the collision of the Archaean nuclei of the Guiana Shield and the West African Craton (2260-2080 Ma; Delor et al., 2003; Kroonenberg et al., 2016). The style of gold mineralisation has been classified as syn- to late orogenic (Voicu et al., 2001; Daoust et al., 2011). Currently, gold is being mined at various locations by small-scale operations as well as major companies. The Rosebel mine, the first large-scale open-pit mine in Suriname, has been in operation since 2000. In 2013, total annual gold production in Suriname was estimated at $807,500 \mathrm{oz}$, of which $c .46 \%$ was produced by the Rosebel mine and the remainder by artisanal miners.

Despite the increasing gold production and interest in the gold sector, there is still a lack of geological knowledge about the origin and evolution of deposits in Suriname, mainly due to the inaccessibility of the tropical rainforest and the deeply weathered overburden. This paper presents a general overview of currently available information on gold mineralisation in Suriname, and discusses recent developments in a regional geological context.

\section{Gold exploration and mining in Suriname}

An extensive review of the history of gold exploration and mining in Suriname can be found in De Vletter \& Hakstege (1998). The exploration for gold in the Guianas started at the 


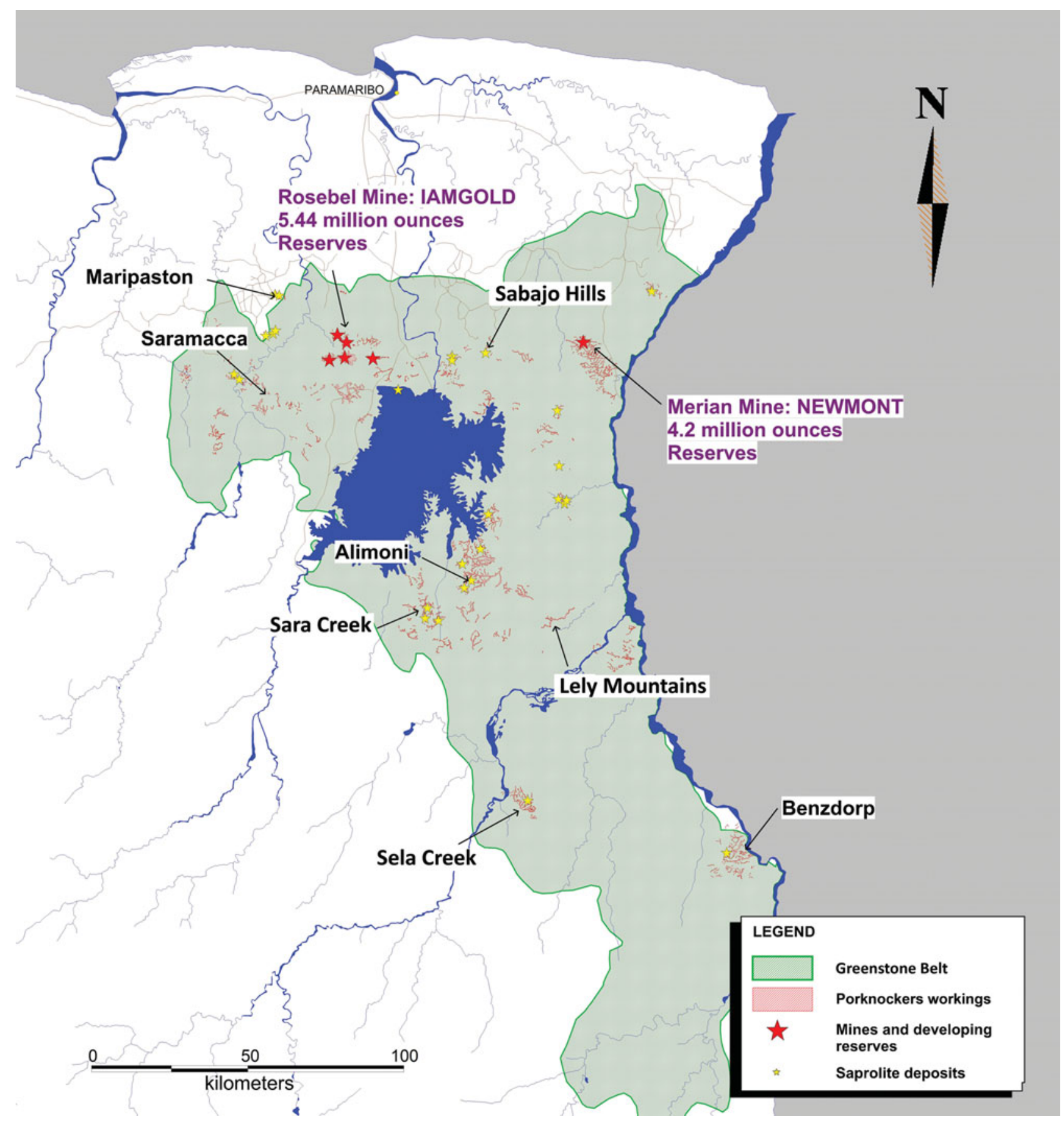

Fig. 1. Map of Suriname showing the main gold occurrences in the NE greenstone belt.

end of the 17th century with the search for the mythical gold region El Dorado along the imaginary Lake Parima.

Suriname's indigenous people had no knowledge of gold at that time, so early expeditions by the Dutch colonising powers in 1687-1688 and 1720 were unsuccessful. In $1736,0.5 \mathrm{~kg}$ of gold dust was exported to the Netherlands, probably from the Van den Bempdenberg along the Suriname River. Serious gold exploration started in the second half of the 19th century, and the years 1874-1912 saw a real gold rush in the interior of the country, of which now only heavily overgrown monuments of industrial archaeology remain (Fig. 2). Subsequent smallscale mining continued at a low level until serious interest in exploration resumed in the 1970s through the activity of the Geological and Mining Service of Suriname.

Since the beginning of the 1990s a new gold rush has developed, involving intensive, often illegal artisanal mining of lateritic and alluvial deposits in many major creeks in the greenstone belt, as well as dredging in the Marowijne River and the Afobaka storage lake (Fig. 3). At the same time, the first large open-pit gold mine was opened in the Gros-Rosebel savannah 


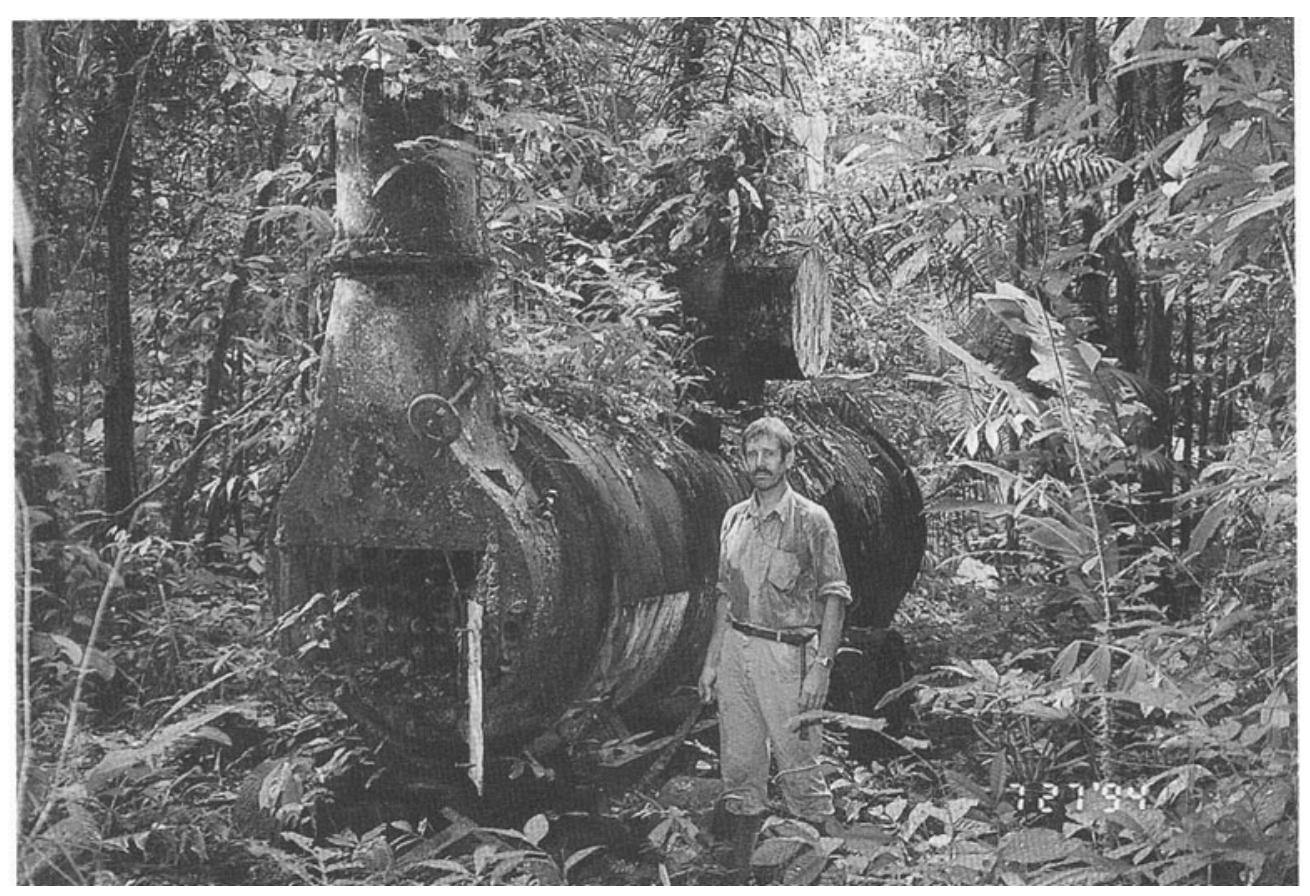

Fig. 2. Steam kettle remaining from gold exploration in the early 20th century at Sara Creek (from De Vletter \& Hakstege, 1998).

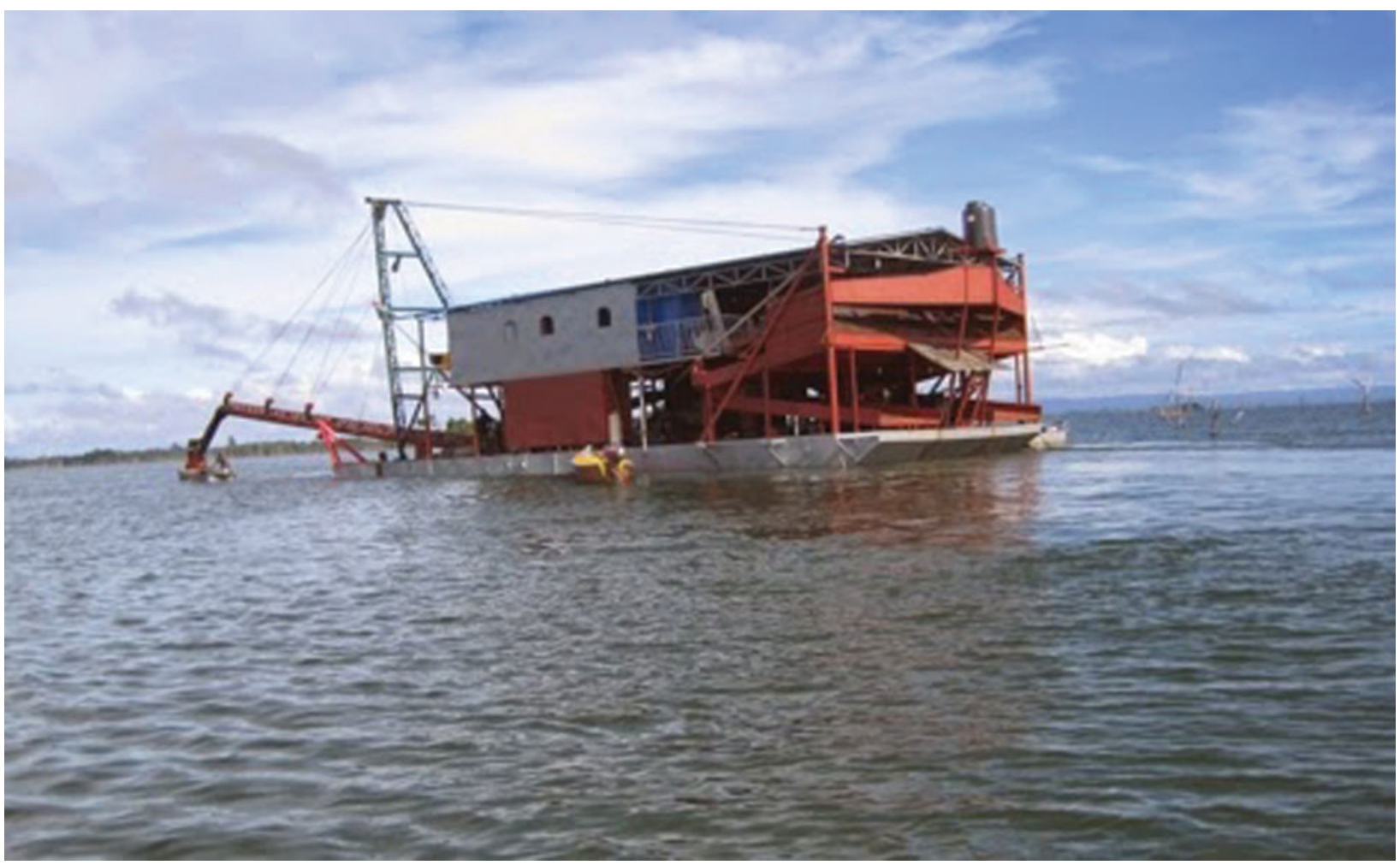

Fig. 3. A scalian (gold dredge) in Afobaka hydropower lake (photograph courtesy of Ronny Asabina).

area, c.80 km south of Paramaribo (Figs 4 and 5). It is operated by Rosebel Goldmines N.V., a subsidiary of the Canadian Iamgold company. Commercial production commenced in 2004. The total proven and probable reserves in 2014 were estimated at 8.6 million ounces at a grade of $1.3 \mathrm{~g} \mathrm{t}^{-1}$, and an annual pro- duction of $325,000 \mathrm{oz}$ was noted at the end of 2014 (Iamgold Corporation, 2014). The mine consists of eight separate pits. The US-based Newmont company is planning to open a second large open pit by the end of 2016 in the Merian area north of the Nassau Mountains (Newmont Mining Corporation, 2014). 


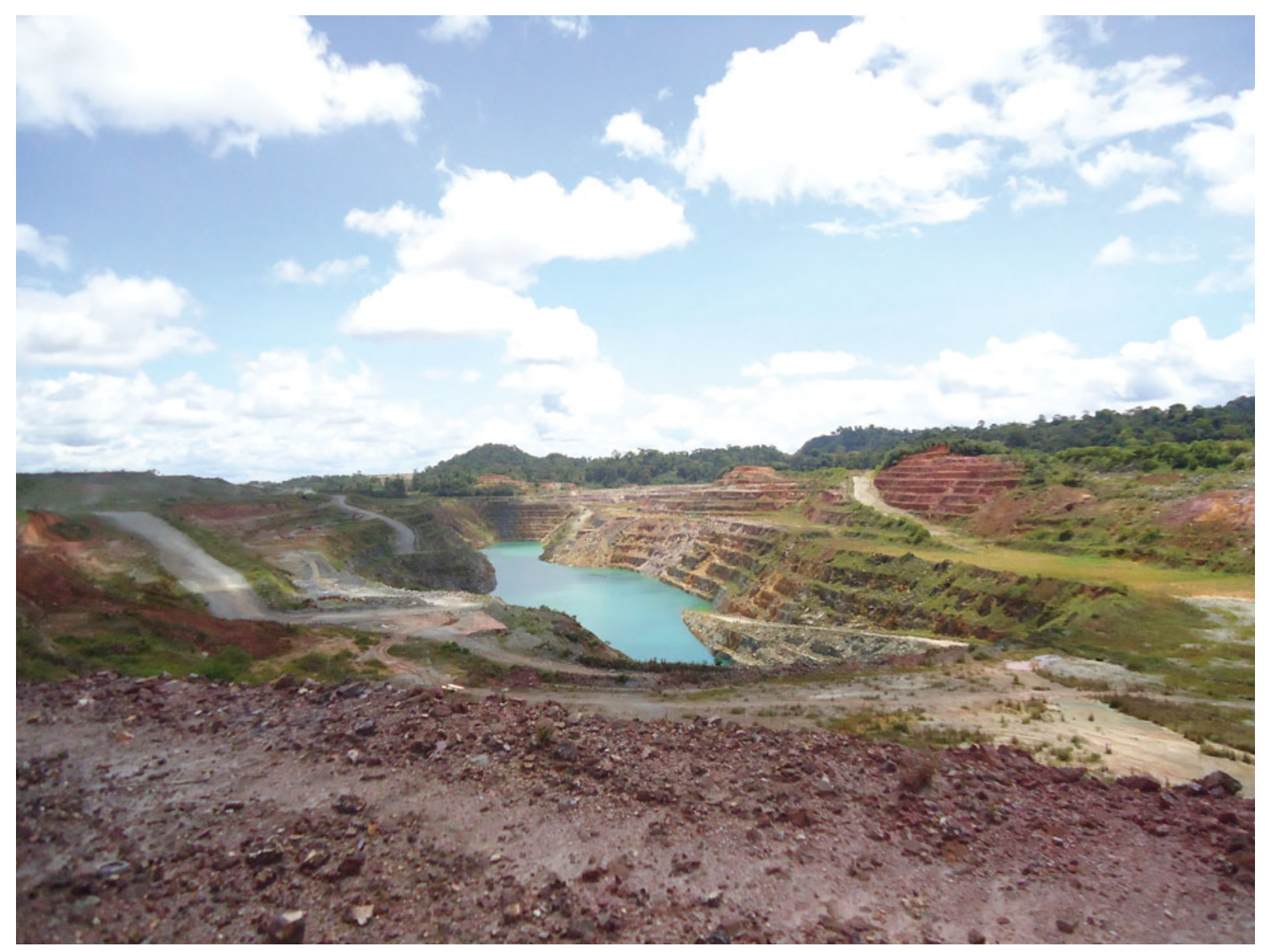

Fig. 4. Pay Caro pit in 2012 (photo: N. Kioe-A-Sen).

A range of smaller foreign and domestic companies (e.g. Golden Star, Canarc, Wylap, NanaResources, Suparna Gold, Hunter Bay Minerals) have been active in exploring and exploiting gold mineralisations in many parts of inland Suriname since the 1990s. The small-scale gold operations are also concentrated in the greenstone belt. The intensity of activities fluctuates with the gold price. Seventy to eighty per cent of the artisanal miners are Brazilians (garimpeiros), and a minority are mostly local maroons (Heemskerk, 2009). They usually mine placer deposits, and use a hydraulicing (sluice boxes) method (Figs 6 and 7) and mercury to recover the gold (Fig. 8).

N.V. Grassalco, a state-owned mining company, has an operation in the Maripaston area, Paradistrict, where tailings (bakasanti) from former small-scale operations are mined and processed, using mercury-free gravity concentration equipment (crushers, grinders, hydrocyclones and shaking tables) to recover the gold (Figs 9 and 10). This modern operation started production in 2014 (Grassalco, 2016).

The current significance of gold for the economy of Suriname can be gauged from its contribution to the country's exports. More than $80-90 \%$ of exports come from the mineral sector, and the importance of gold has grown rapidly in recent years. The share of gold in total exports more than doubled in the first decade of this century. In 2014 its contribution was 54.5\%, significantly more than alum earth (16.5\%) and oil (15.1\%) (De Vletter et al., 1998; Centrale Bank van Suriname, 2014a,b).

\section{Gold deposits in Suriname}

In Suriname, the Guiana Shield comprises the 2.26-2.09 Ga Marowijne Greenstone Belt and two 2.07-2.05 Ga high-grade metamorphic belts, the Bakhuis Granulite Belt and Coeroeni Gneiss Belt, surrounded mainly by granite and gneiss bodies and felsic metavolcanics. A remnant of the sub-horizontal Roraima Formation is located at Tafelberg in the centre of the basement area. Proterozoic and Early Jurassic dolerite dikes intruded into the whole basement (Bosma et al., 1977, 1984; De Vletter, 1984a,b; Kroonenberg et al., 2016)

Gold mineralisation is essentially restricted to the Marowijne Greenstone Belt, which contains three main metavolcanic-metasedimentary formations. The Paramaka Formation consists mainly of ocean-floor metabasalts, locally with 


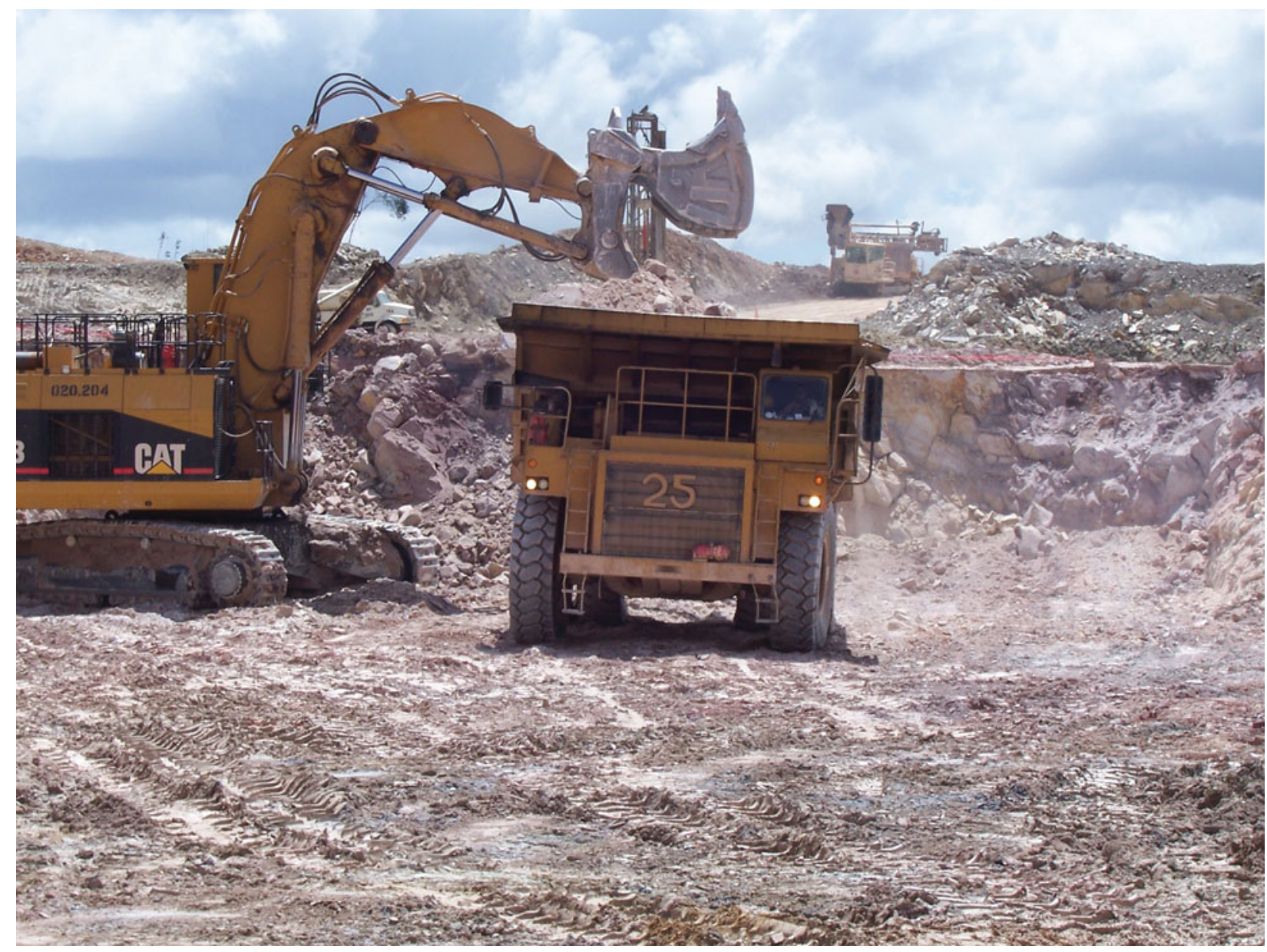

Fig. 5. Mining at the Pay Caro Pit (photo: N. Kioe-A-Sen).

pillow structures, and a series of island-arc meta-andesites to metarhyolites and intercalated volcanogenic and chemical sediments. The Armina Formation is composed of a series of metagreywackes and phyllites and minor conglomerates, deposited as turbidites in a deep-marine environment (Naipaul \& Kroonenberg, 2016). The Rosebel Formation consists of more mature sandy sediments, deposited in an epicontinental environment.

All three formations show low-grade metamorphism in the greenstone facies. The greenstone belt is intruded by trondhjemite-tonalite-granodiorite (TTG) diapiric bodies, which usually show conformable contacts with the surrounding metamorphic units. Around these intrusions metamorphism reaches amphibolite-facies grade.

It has long been recognised that gold mineralisation in Suriname produced primary as well as secondary deposits (Brinck, 1955; Dalhberg, 1984). The primary deposits are generally associated with quartz- and quartz carbonate veins bound to lithological contacts, fold structures and sub-vertical shear corridors. Gold at lithological contacts between granitoids and adjacent rocks (Brinck, 1955; De Vletter, 1984a,b) led Brinck (1955) to propose a genetic relationship with the basement intrusives.
Secondary or placer accumulations occur as colluvial and alluvial deposits from weathered material in terraces of recent or abandoned rivers and streams (Dalhberg, 1984; De Vletter \& Hakstege, 1998).

From the distribution of gold concessions on old maps, Brinck (1955) distinguished three areas of gold occurrences: (1) an E-W-trending area from the Marowijne River to the Saramacca River (Nassau, Rosebel, Mindrinetti-area), (2) a NWSE-trending area with the Sara Creek and Boven-Grankreek prospects and (3) the Drietabbetjekreek and Oelemari area (Fig. 1). From recent exploration and mining activities, gold enrichments appear to follow two major zones: one with an EW orientation (including Rosebel, Nassau and Maripaston) and the other with a NW-SE tendency (including Sara Creek, Lely Mountains and Benzdorp). These areas in the eastern greenstone belt host the majority of large-, medium- and small-scale operations, but gold also occurs in the Apoera area in west Suriname. The only recent comprehensive study on Surinamese gold deposits is devoted to the Rosebel district (Daoust et al., 2011), where the ores classify as orogenic deposits, in line with other major gold occurrences of the Guiana Shield (Voicu et al., 2001). 


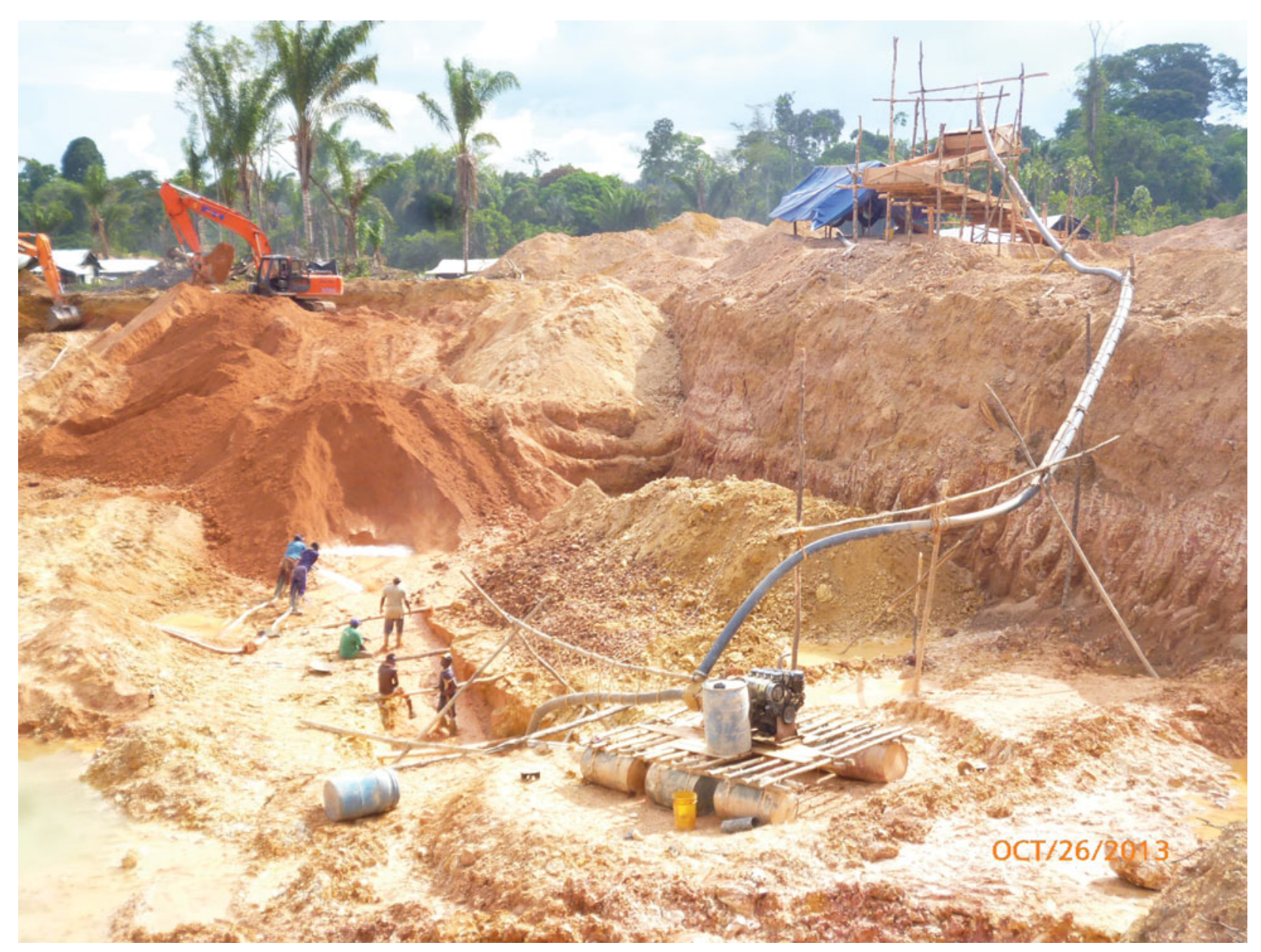

Fig. 6. Mechanical hydraulicing ('soigi spoiti') operation at Koemboekreek, south of Rosebel concession (photo: R. Finkie).

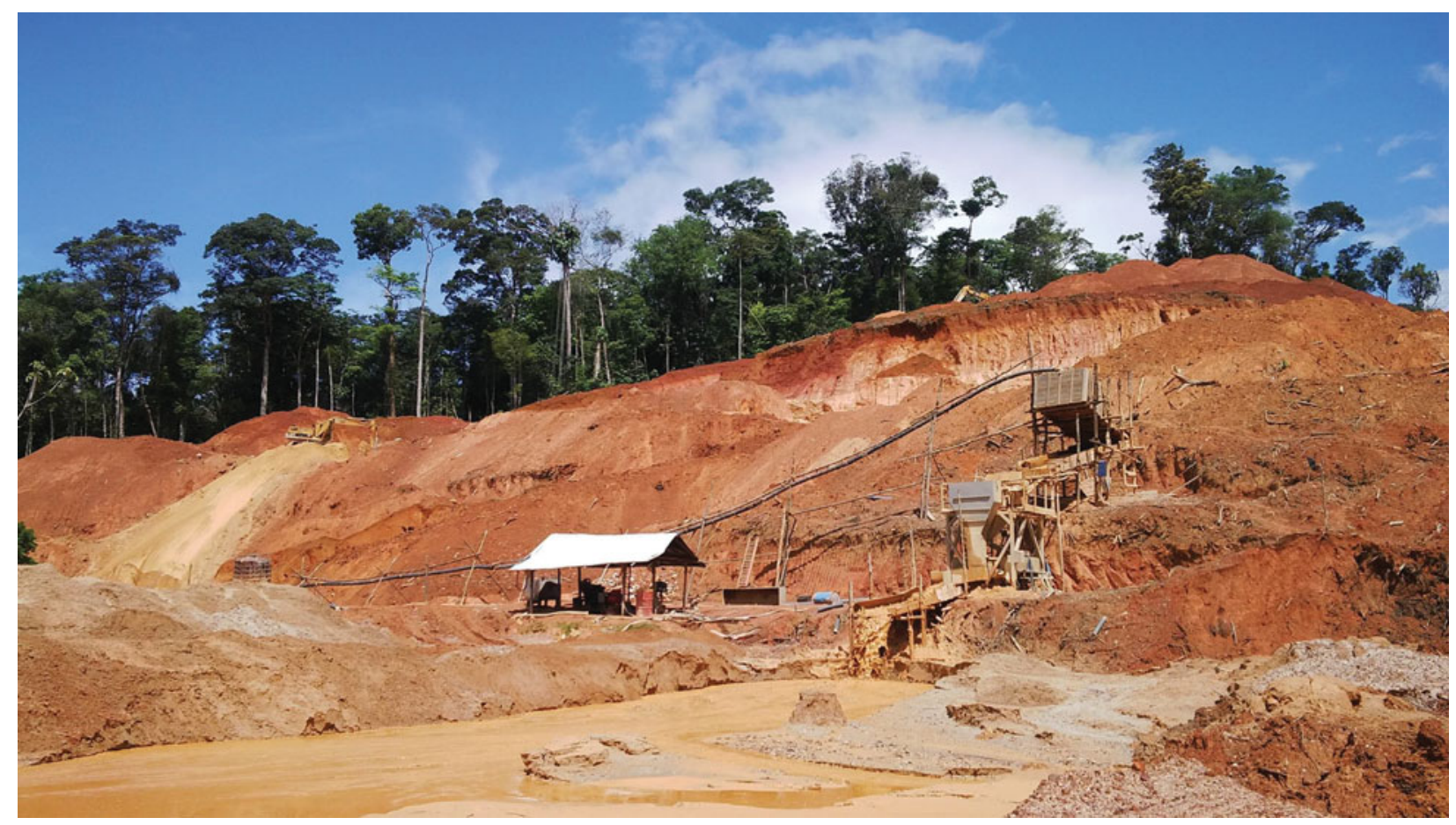

Fig. 7. Small-scale mining operation at Antino, Benzdorp (photo: Sh. Sheikkariem). 


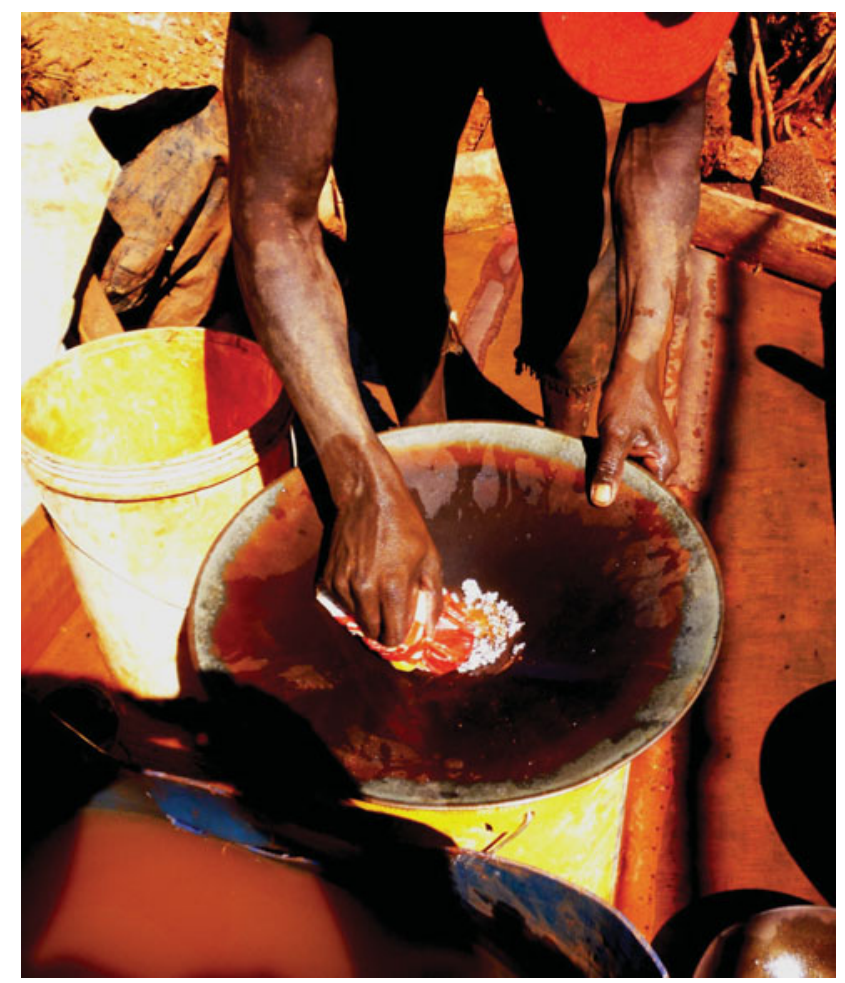

Fig. 8. Mercury recovery of gold in batea (gold pan) (photo: R. Finkie).

\section{The E-W gold belt: Rosebel, Merian and Nassau}

Rosebel The belt hosts two major gold deposits, Rosebel and Merian. The Rosebel gold mines are located in the Brokopondo District, c.80 km from the capital city of Paramaribo. It is the first and currently only large-scale open-pit mine in Suriname. Following the first discovery of gold in 1879, some 600 smallscale mining operations were active in this area (P.M. Johnson, unpublished report, 2002; G. Voicu, unpublished report, 2010). Several companies (e.g. Goldenstar) explored and exploited the area in the past. Cambior commenced commercial production in 2004; Iamgold Corporation acquired Cambior in 2006 and has continued the operation since then. Approximately half of total gold production in Suriname has been extracted from the Rosebel area since its discovery. In 2014 annual production was 325,000 oz (Iamgold Corporation, 2014).

The Rosebel gold district currently consists of eight identified deposits and several prospective areas (Fig. 11). The geological setting and mineralisation have recently been treated in detail (Daoust et al., 2011; Daoust, 2016). The deposits are located within three mineralised zones along two major structures: North (Koolhoven, J-Zone and Pay Caro), Central (Rosebel deposit) and South (Mayo, Royal Hill and Roma). The northern deposits are to a significant extent associated with turbiditic sequences (mudstone-siltstone-greywacke) in contact with volcanic rocks, while the southern deposits exhibit an association with a tonalitic intrusion, and the central deposit an arenitic sequence.
The Rosebel deposits are hosted in greenschist-facies metamorphosed volcano-sedimentary lithologies of the Armina and Rosebel Formations. The gold mineralisation is associated with shear- and tensional quartz-carbonate veins along structural features (fold hinges) and stratigraphic contacts (Fig. 12). The main vein mineralogy is a quartz-carbonate-tourmaline-pyrite assemblage, with some distinct varieties between the different trends. A wall-rock alteration assemblage of sericite, chlorite, carbonate, tourmaline, pyrite, pyrrhotite and plagioclase typically surrounds the mineralised quartz veins (Fig. 13).

The 0verman deposit, a prospective area $16 \mathrm{~km}$ north of the main deposits (Fig. 11), is an exception. Here, the gold is not associated with quartz veins but is finely disseminated in a large undifferentiated silica body, suggesting a different style of mineralisation. According to initial results of ongoing research, the silica-rich rocks (usually $>90 \% \mathrm{SiO}_{2}$ ) contain visible gold in mineral assemblages that predominantly consist of arsenopyrite, pyrite and pyrrhotite (Kioe-A-Sen, unpublished report, 2012).

The Rosebel deposits carry characteristics of orogenic gold deposits (Daoust et al., 2011; Daoust, 2016), consistent with the regional involvement in the Trans-Amazonian orogenesis (2260-2080 Ma; Delor et al., 2003; Kroonenberg et al., 2016). Delor et al. (2003) suggested a volcanic arc setting for the Armina Formation, whereas according to Daoust (2016) the Armina and Rosebel formations may have formed simultaneously in pull-apart basins during the late stages of the TransAmazonian orogeny. In the Rosebel area, all veins cut the deformed sedimentary rocks of both formations, indicating that gold mineralisation occurred late in the geological history. Although the exact timing of the mineralisation is not constrained, correlation with other gold deposits in the Guiana Shield suggests that the gold mineralisation could have occurred at 2.023-1.955 Ga (Daoust et al., 2011). Gold mobilisation was probably driven by crustal thinning or a subductionrelated plutonic (intrusive?)-volcanic event in the southern part of the Guiana Shield, associated with a post-collisional tectonic setting.

Apart from the primary deposits, secondary gold is also being mined at Rosebel. It is concentrated in large parts of the lateritic cover as a result of remobilisation in the underlying bedrock and saprolite by variations in groundwater levels (Fig. 14). This secondary gold occurs as free coarse grains or is attached to iron (hydr)oxides (P.M. Johnson, unpublished report, 2002; G. Voicu, unpublished report, 2010).

Merian In the northeastern part of Suriname, c. $66 \mathrm{~km}$ south of Moengo and c. $30 \mathrm{~km}$ north of the Nassau Mountains near the border with French Guiana, the Merian Gold Project is planned to commence in late 2016 as a large-scale open-pit mine operation. The project will be carried out by the Suriname Gold Company LLC (Surgold), which started as a joint venture between Newmont Mining Corporation (Newmont) and Alcoa World Alumina 


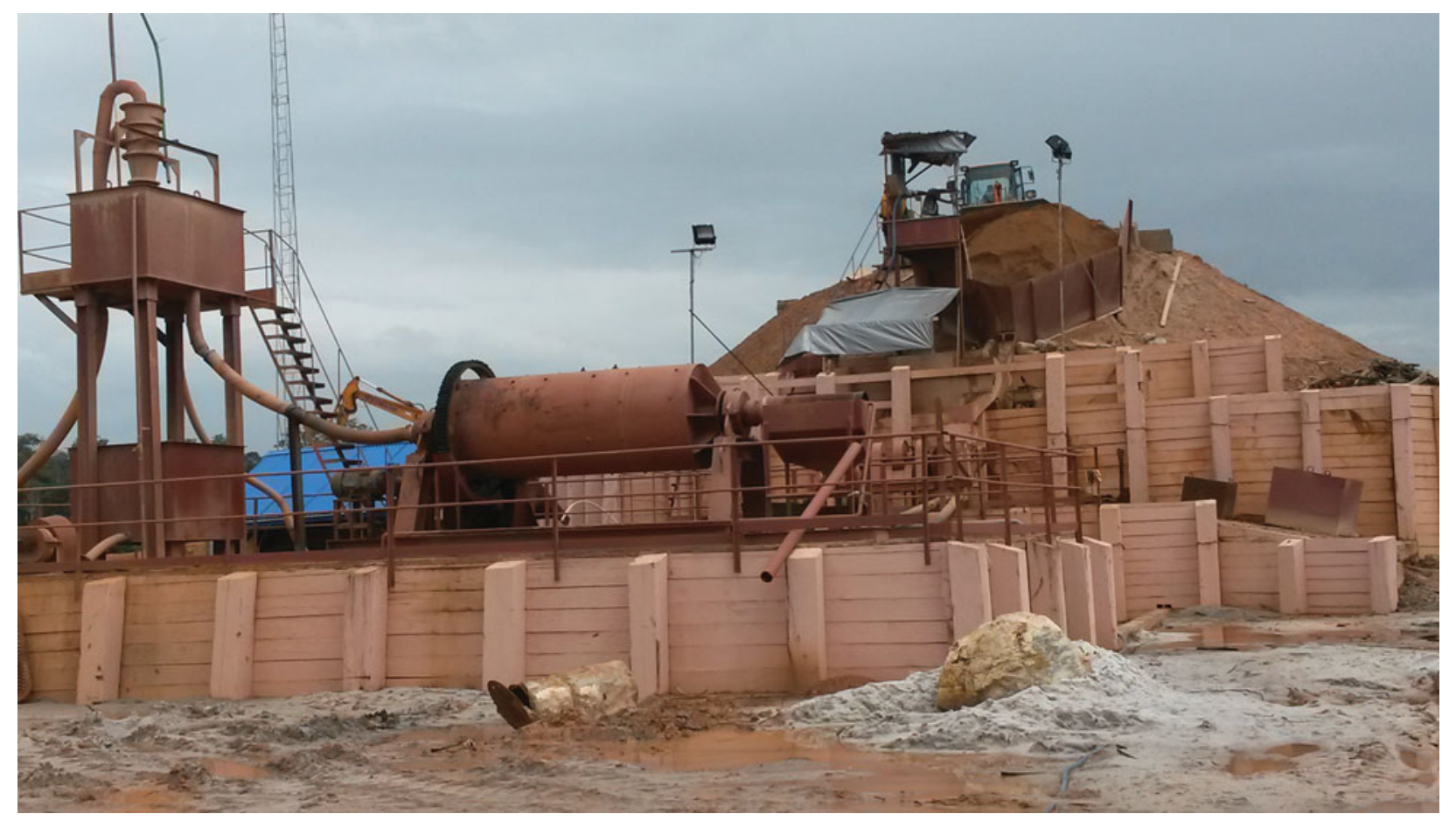

Fig. 9. Maripaston gravity concentration plant (photo: R. Finkie).

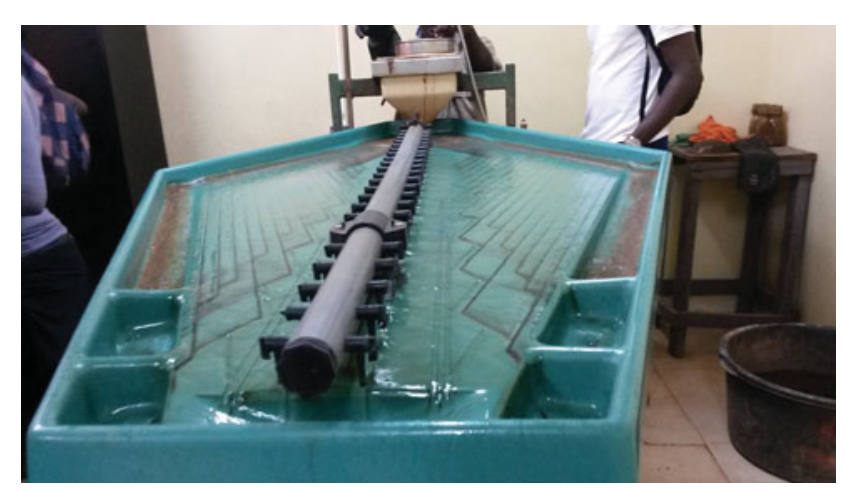

Fig. 10. Shaking table at Maripaston gravity concentration plant (photo: $R$. Finkie).

(Alcoa). Since the departure of Alcoa from Suriname in 2015, Newmont has operated the project. Suriname will participate for 25\% through Staatsolie Maatschappij Suriname N.V. Several open pits with gold reserves of c.4.2 million ounces are aimed to yield an estimated annual production of 300,000-400,000 oz over a mine life of 11 years (Newmont Mining Corporation, 2014). Geological information on the Merian area is sparse. The following overview is based on initial investigations by J.W.A. Ribeiro et al. (unpublished paper, 2007).

In the 1990s, the Merian area was the target of small-scale mining activities as part of an alluvial gold rush. Systematic exploration, started by Alcoa in 1999 (Capps, 2004; Capps et al., 2004), identified near-surface gold mineralisations (Merian I, Merian II, Maraba) along a NW-trending $25 \mathrm{~km}$ long and 5-
$10 \mathrm{~km}$ wide belt (Fig. 15). They are hosted in strongly deformed metasedimentary sequences of the Armina Formation, which is part of the Palaeoproterozoic Marowijne Greenstone Belt (Bosma et al., 1984; Kroonenberg et al., 2016). The Armina lithologies in the area are interpreted as a flysch-turbidite sequence, derived from erosion of volcanics from the older Paramaka Formation. The rocks were metamorphosed to lower greenschist-facies grade during the Trans-Amazonian orogenesis. Tropical weathering conditions created a deep, up to $100 \mathrm{~m}$ thick profile of mostly residual laterite.

The Merian structure is interpreted as an antiform with an axis plunging $20-30^{\circ} \mathrm{SE}$ and with tight, parasitic folds on both limbs (Fig. 16). Gold mineralisation seems to be associated with these folds, NW-trending faults, shear zones and lithological contacts (Figs 16 and 17). It is mainly associated with quartz veins but may also be disseminated several metre into the adjacent wall rock. Associated sulphides consist mostly of pyrite, with minor amounts of chalcopyrite, bornite, sphalerite and galena. Although alteration and mineralogy seem uniform, there are differences in structural style between the deposits (Fig. 17). The Maraba deposit (1 km long and $300 \mathrm{~m}$ wide) occurs within a series of sheeted quartz veins with a steeper NE dip than the Merian II deposit (2.5 km long and 0.5-0.7 km wide), which is associated with quartz breccia and adjacent sheeted, stockwork and folded quartz veins. Also, the Maraba deposit shows a more regular geometry, is more continuous and extends deeper, presumably because of its location along the NE limb of the proposed antiform, while the Merian II might be closer to the fold hinge. 


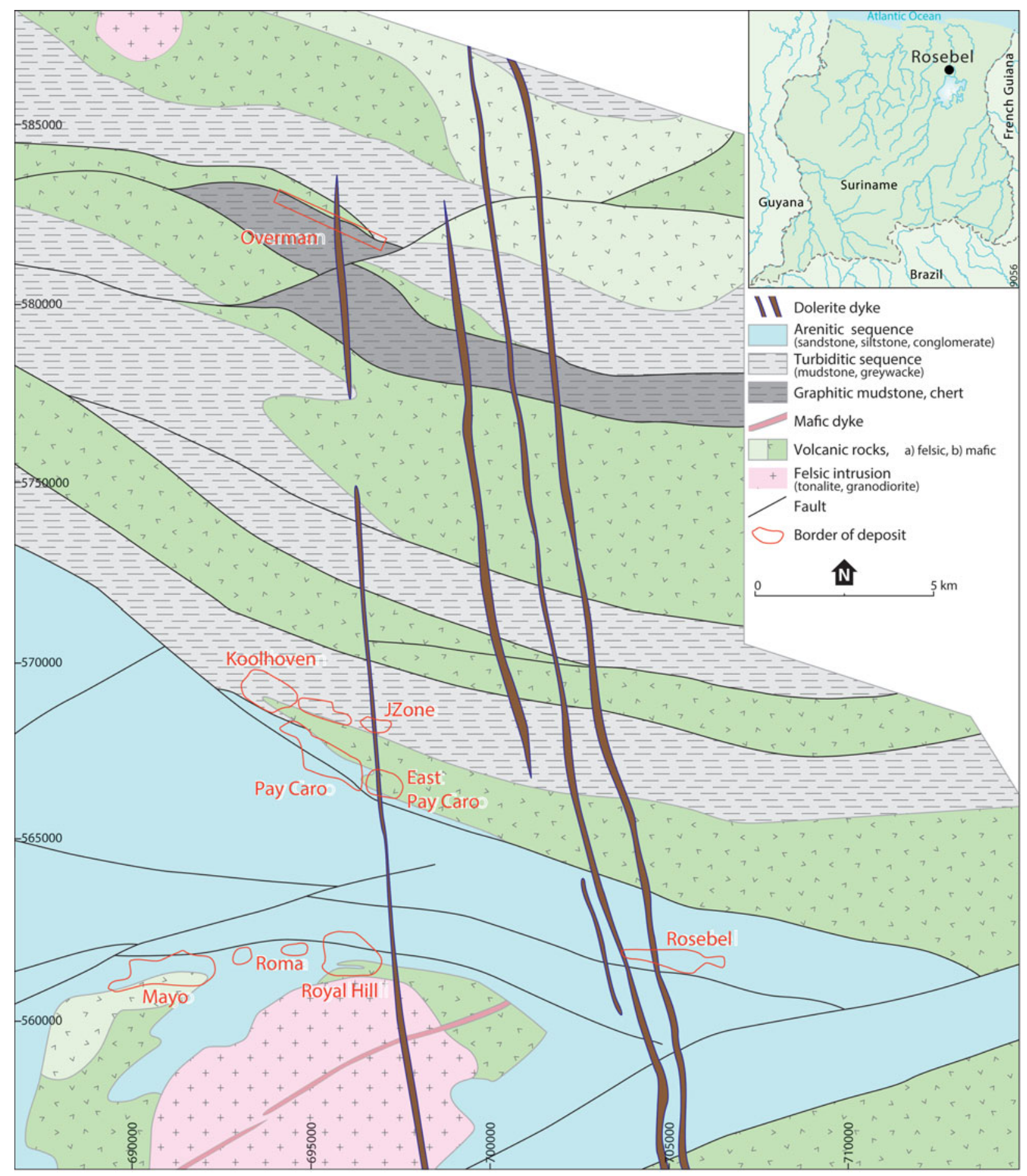

Fig. 11. Geological map of the Rosebel area (adapted from Daoust et al., 2011).

The timing of gold mineralisation and hydrothermal alteration, relative to regional metamorphism, is uncertain. Mineralising processes may have occurred in several phases, presumably simultaneous with or after the metamorphic peak. The currently known characteristics of the Merian setting suggest a preliminary classification as epigenetic-mesothermal gold-only deposits, belonging to the orogenic family. According to Capps et al. (2004), based on a study of the
Gowtu Bergi in the Merian Creek area, the gold mineralisation is mainly associated with tension gash veins within shear zones.

The Sabajo Hills gold prospect, c. $40 \mathrm{~km}$ west of the Merian deposits (Fig. 1), might be associated with a regional fault structure connecting the northern pits of the Rosebel gold mines and Merian I. The structure, interpreted as a major strikeslip fault complex, may have accommodated fluid flow, rock 


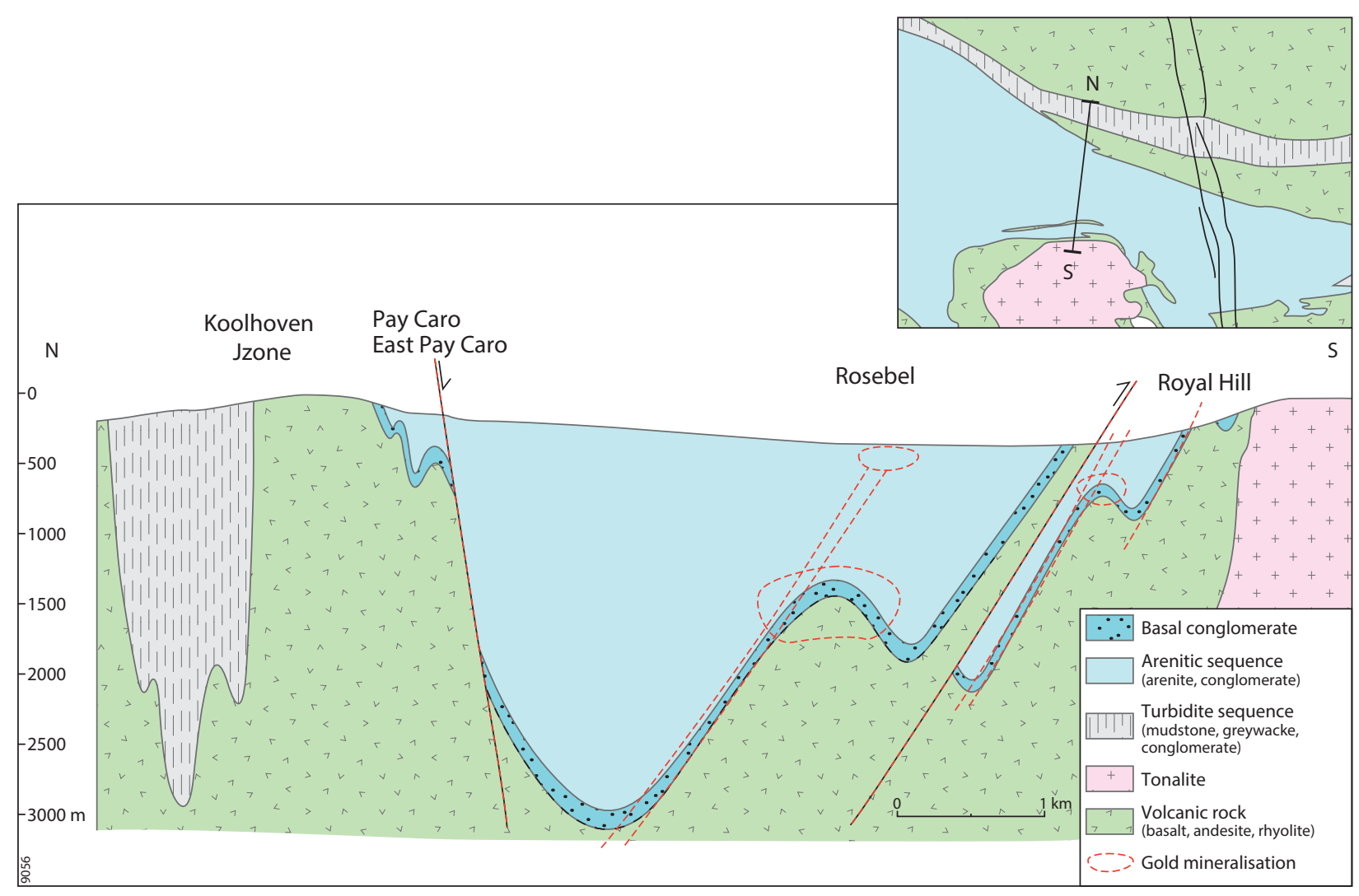

Fig. 12. North-south cross section of the Rosebel area (adapted from Daoust et al., 2011).

alteration and primary gold mineralisation (see Bijnaar et al., 2016). Information on the local geology, mineralisation and resource potential of the Sabajo Hills prospect is scarce. According to a preliminary study (Patadien, 2013), the lithology consists of alternations of metavolcanic and metasedimentary rocks located within a shear zone.

Nassau The Nassau Plateau, situated $20 \mathrm{~km}$ south of the Merian Project within the Marowijne Greenstone Belt, has long received attention as a potential source of gold, mercury and bauxite. Mineral exploration of the Nassau Plateau started in the early 1900s. Surveys were carried out in 1917 by the Nederlandse Mijnexploitatie en Exploratie Maatschappij (NENIEM); in 1925 by the Surinaamsche Bauxiet Maatschappij (SBM), a subsidiary of Alcoa; in 1951-1953 by the Geologische Mijnbouwkundige Dienst Suriname (GMD); and in 1958 by Suralco-Alcoa (Aleva \& Wong, 1998). The most recent surveys, targeted at gold, were carried out under the auspices of Sumin Resources (R.C. Capps, unpublished report, 2014).

The Nassau Plateau is largely made up of mafic to intermediate and minor ultramafic and felsic volcanic and intrusive rocks, interbedded with volcaniclastics, attributable to the Paramaka Formation. Both primary and placer gold has been found on the northern and western side of the plateau, near the boundary with the terrigenous clastic sedimentary and minor volcanic rocks of the Rosebel Formation. All these rocks are strongly folded and experienced low-grade greenschist facies metamorphism (R.C. Capps, unpublished report, 2014).

During more than a century, artisanal miners (porknockers) have explored the area for placer gold within Tertiary to Recent gravels. Most of the workings are centred in streams draining the central Nassau Plateau. The Witlage Creek is an exceptional site because of the discovery of large alluvial cinnabar nuggets in 1912, which prompted exploration surveys for mercury in the early 1900s and 1950s (Billiton internal report, 1953). Historically, its drainage system hosts the most active gold placers.

In-depth geological studies of gold mineralisation in the Nassau concession are lacking. From a new reconnaissance survey in 2001, Capps et al. (2004) identified different bedrock sources for the placer gold and mercury of the Witlage Creek: (a) discontinuous cinnabar-pyrite gold veins along the contact between metamorphosed mafic rocks and overlying arenites, with gold in mafic rocks being associated with $\mathrm{Pt}, \mathrm{Fe}$ enrichment, $\mathrm{P}$ and $\mathrm{Ti}$, and native mercury being common in the mafic rocks as well; (b) andesite hosting vein gold with sulphides in a zone of stockwork quartz veining, alteration, and As enrichment; (c) near the contact of an intrusive gabbro. 


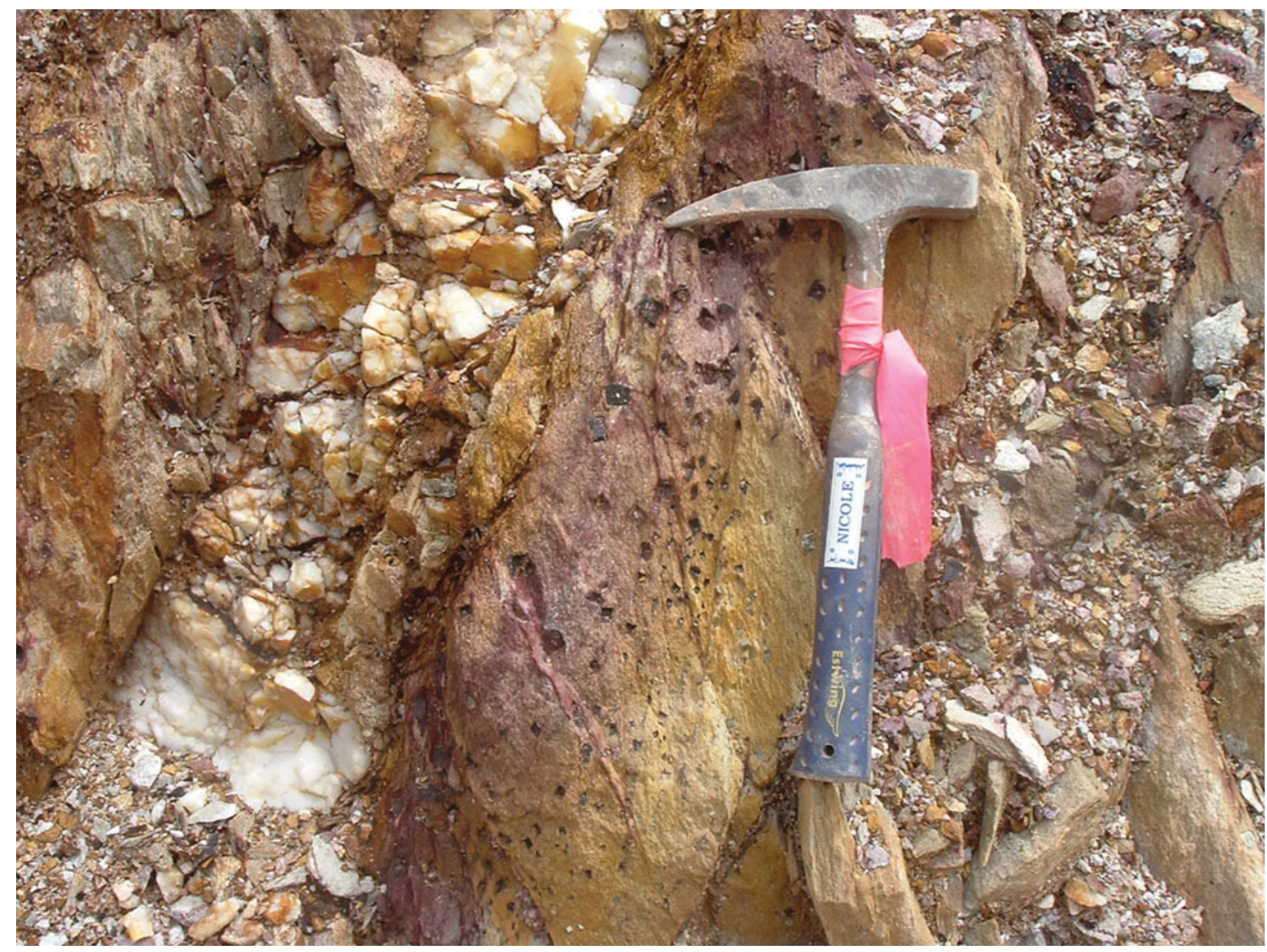

Fig. 13. Mineralised quartz vein with pyrite in the wall rock (photo: N. Kioe-A-Sen).

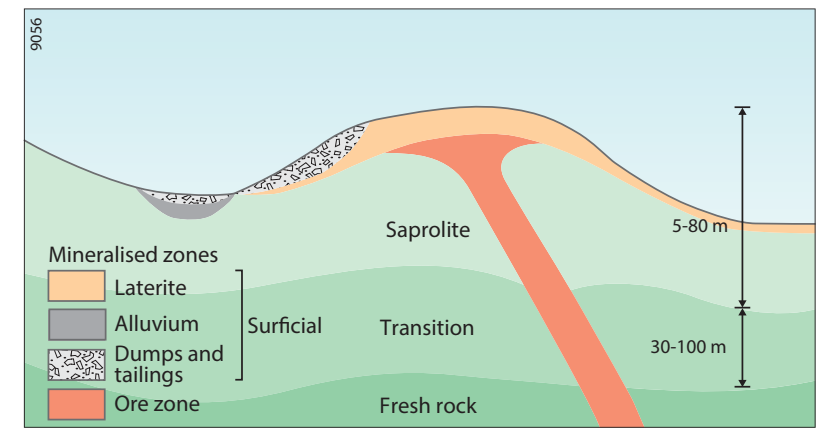

Fig. 14. Schematic profile indicating the relationship between primary and secondary gold deposits in the Rosebel area (modified after P.M. Johnson, unpublished report, 2002).

\section{The NW-SE gold belt: Sara Creek, Lely Mountains, Benzdorp and Sela Creek}

The Sara Creek and Lely Mountains gold projects are located in central Suriname, and the Benzdorp project in the SE part (Fig. 1). Due to their remoteness and difficult accessibility, systematic exploration has been limited, and large-scale operations have not been developed so far. For the past century, these areas have been marked by modest mining operations where local and Brazilian miners (garimpeiros or porknockers) work and rework mainly alluvial material. Gradually, modern methods such as open pit and underground shafts and drifts (Fig. 18) were introduced, and saprolitic materials and quartz veins are mined as well. Sara Creek has long been known for extensive mining of placer gold. The largest production from small-scale goldmining $(1209 \mathrm{~kg}$ ) in history came from Benzdorp (De Vletter \& Hakstege, 1998). Although foreign exploration companies executed exploration programmes, geological information on these areas remains scarce. The following brief overview is based on technical reports on potential gold resources (A. Fleming, unpublished report, 2006; D. LaPoint, unpublished report, 2008; J.G. Moors, unpublished report, 2008).

The geology of the Sara Creek area extends along a major $\mathrm{N}-\mathrm{S}$ trend, with a sequence of predominantly metavolcanicsedimentary (andesites, cherts and phyllites) on the west side, and mafic volcanic and intrusives in contact with a large tonalitic batholith to the east. Airborne magnetic and structural data suggest that primary gold mineralisation is mainly concentrated at lithological contacts, generally associated with 


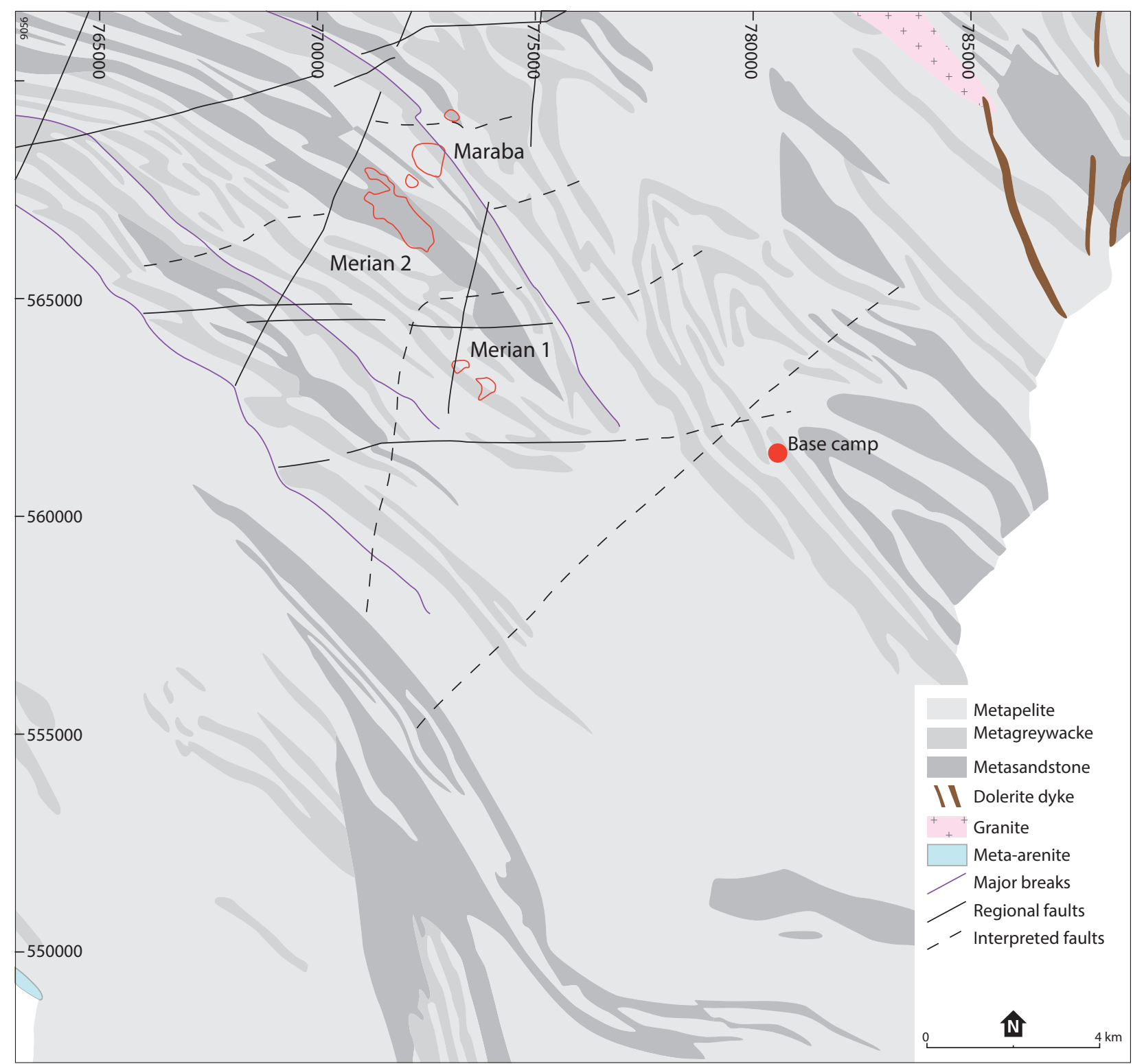

Fig. 15. Schematic geological map of the Merian deposit, based on J.W.A. Ribeiro et al. (unpublished paper, 2007).

shearing and with pyrite and carbonate alteration in the wall rock. Gold mineralisation may also be controlled by structures that obliquely intersect this main trend and by NW- and NEdirected thin mafic dikes and sills, which could point to an intrusive relationship (D. LaPoint, unpublished report, 2008).

The geology of the Lely Mountains $(600-700 \mathrm{~m}$ high plateaus) is poorly known because of deep weathering and dense vegetation. According to the geological map of Bosma et al. (1977), the area consists of NE-striking metabasalt, gabbro-norite and amphibolite. Exploration for bauxite in the early 1970s yielded indications for copper and zinc enrichments associated with pyrite, chalcopyrite and arsenopyrite. Miedema (unpublished notes, 2007) proposed that the Lely project is underlain by a SW-plunging anticlinorium and syncline. D. LaPoint and A. Fleming (unpublished report, 2008) suggested that gold mineralisation is associated with significant shear zones. Cur- rently, the only gold production in the area is from artisanal mining of alluvial gravels and colluvial material.

The hilly NE part of the Benzdorp area (Fig. 19) belongs to the eastern greenstone belt. Here, a succession of roughly NNWSSE-trending metavolcanics and minor metacherts and phyllites of the Paramaka Formation is folded in an open arcuate syncline with an E-W-trending fold axis and its concave side to the east. The arc gradually tightens eastwards to a nearisoclinal fold in the lower part of Antino Creek. The lithological succession from west to east and from bottom to top is basement gneiss overlain by an assemblage of amphibolites and chlorite-sericite schists, followed by greywacke and coarse volcanoclastic agglomerate near the border of the Lawa River. Geophysical surveys suggest a continuity of the tectonic style into French Guiana (S. Miedema, pers. comm., 2016). Intrusive bodies are widespread, with many containing gold mineralisation. 


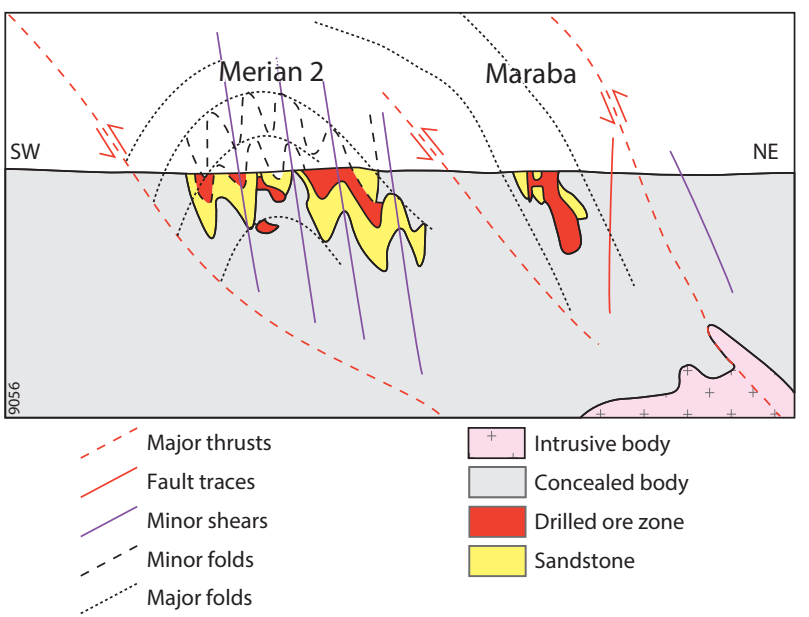

Fig. 16. Schematic SW-NE geological section of the fold-and-thrust system along the Merian trend, illustrating the tectonic setting of the Merian II and Maraba deposits (after J.W.A. Ribeiro et al., unpublished paper, 2007)).
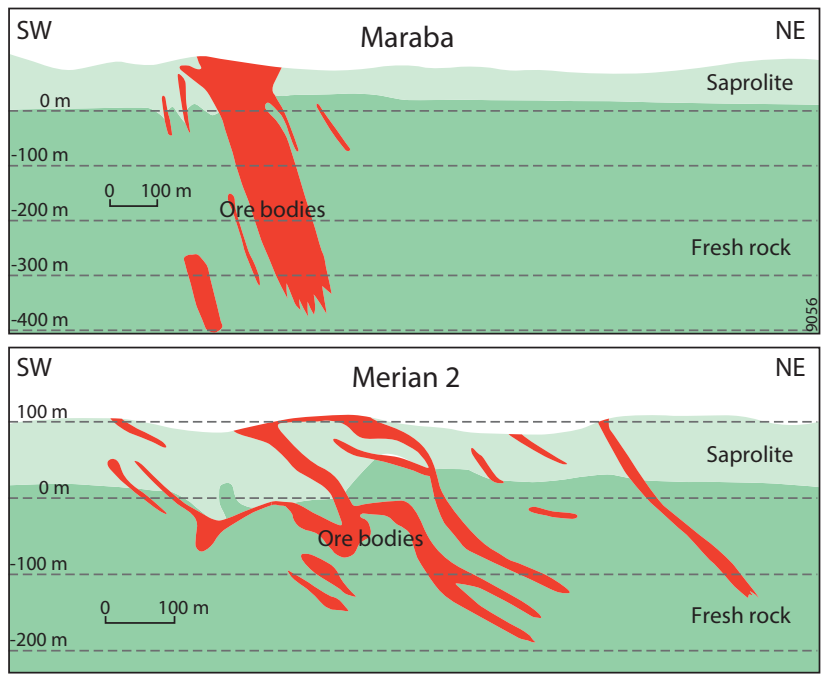

Fig. 17. Schematic SW-NE sections of the Maraba and Merian II deposits showing the distribution of ore bodies in detail (based on J.W.A. Ribeiro et al., unpublished paper, 2007).

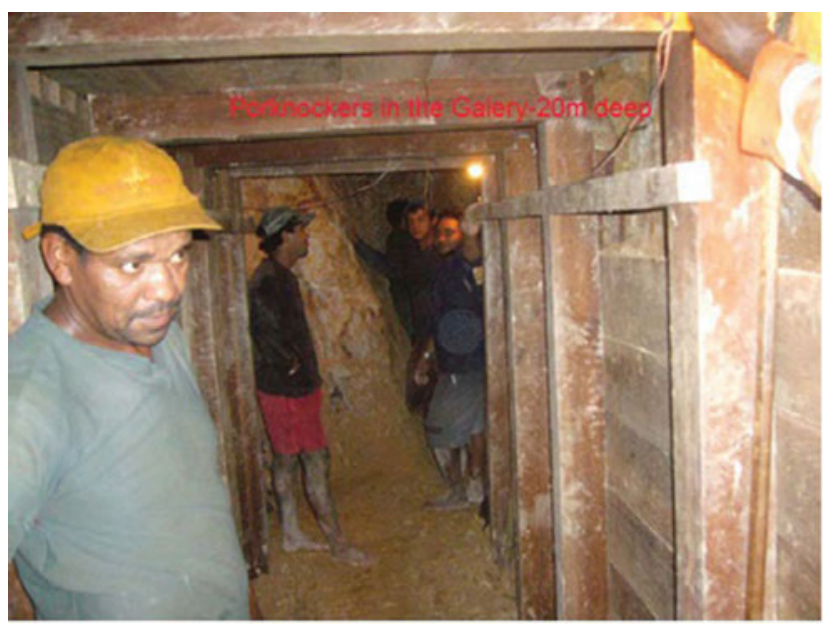

Fig. 18. Underground mining at Filao, Sara Creek (photo: D. LaPoint).
Several tonalitic intrusives occur in the chlorite-sericite schists, whereas relatively small intrusives with a variety of compositions (mafic-intermediate-felsic) have also been found in the greenstone belt closer to Benzdorp (J.G. Moors, unpublished report, 2008; not shown in Fig. 19). Biotite granites and biotite tonalites dominate the western part of the Benzdorp area, which is referred to as basement gneiss. The central-southern part is composed of an assemblage of NW-striking metavolcanic lithologies and several gabbroic bodies, of which the De Goeje Gabbro is the largest (Fig. 19).

The nature of gold mineralisation in the Benzdorp area has not been established with certainty yet. Locally, gold has been found associated with copper and a tonalite stock that intruded into mafic-intermediate volcanic rocks. This might hint at a copper-gold porphyry-type deposit (J.G. Moors, unpublished report, 2008), but exploration data are insufficient to confirm this. Elsewhere, mineralisation occurs along a NNEtrending shear zone hosting gold-bearing quartz veins similar to those in the Rosebel area (De Vletter and Hakstege, 1998; J.G. Moors, unpublished report, 2008). Other structural controls probably played a role as well, since gold has also been found in tight isoclinal fold hinges (S. Miedema, 2016, pers. comm.). In the 1930s, platinum-group minerals were discovered in alluvial deposits.

The Sela Creek area, located west of the Benzdorp concession (Fig. 1), is marked by extensive artisanal workings targeting gold in saprolitic alteration products of bedrock, which predominantly consists of metavolcanics and metasedimentary rocks. The alluvial workings cover an area of $40 \mathrm{~km}^{2}$ and include numerous shallow open pits aligned along a $c .7 \mathrm{~km}$ long NW-SE-trending mineralised strip. According to reconnaissance geophysical and geochemical explorations, the array of gold prospects is hosted in a regional shear zone, where gold is associated with sheeted quartz veins and limonite-stained silicaaltered zones in strongly deformed rock units of the greenstone belt (A. Tunningley, unpublished report, 2012).

\section{Gold mineralisation in a regional context}

The gold deposits and occurrences in Suriname are part of a major zone of gold mineralisation in the Palaeoproterozoic granitoid-greenstone belt of the Northern Guiana Shield, which runs from Venezuela to NE Brazil (Fig. 20; Gibbs \& Barron, 1993; Voicu et al., 2001; Dardenne \& Schobbenhaus, 2003). Apart from Rosebel and Merian in Suriname, gold mines and near-mine projects in the Guiana Shield include Choco-10 and Las Cristinas in Venezuela, Tassawini, Aurora, Peters Mine (abandoned) and Omai (abandoned) in Guyana, Yaou/Dorlin and Camp Caiman in French Guiana and Amapari, Volta Grande and Gurupi in NE Brazil.

Most gold deposits and occurrences are located near major structures and are linked with low- to medium-grade metamor- 


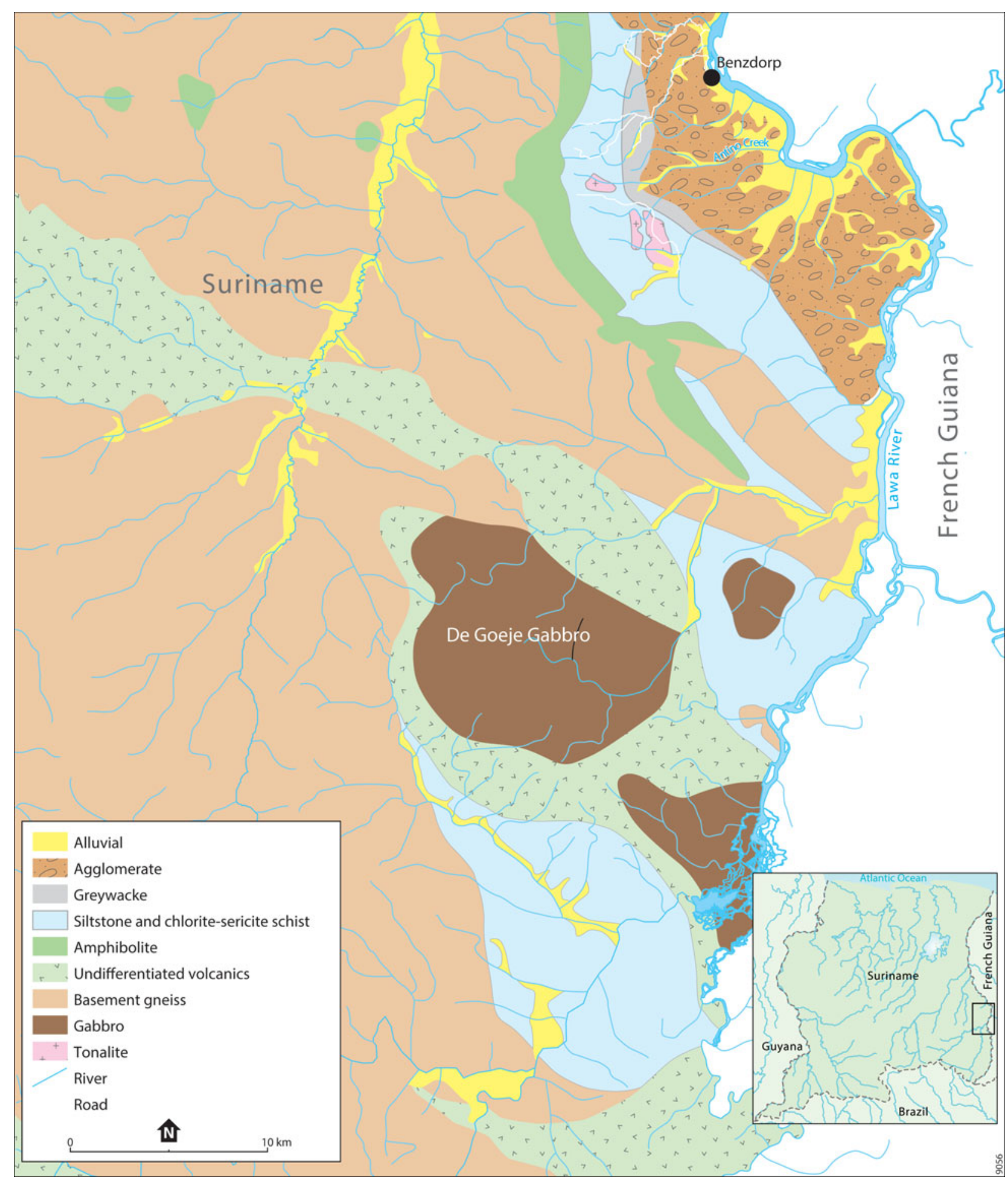

Fig. 19. Geological map of the Benzdorp area (based on J.G. Moors, unpublished report, 2008 and S. Miedema, 2016, pers. comm.).

phic sequences, while at a local scale they are often associated with syn- to late-tectonic quartz veins (Voicu et al., 2001). They are hosted in a range of different lithologies of the granitoidgreenstone belt: lavas, banded-iron formations (BIFs), turbiditic sedimentary sequences, intrusives and conglomerates. 0mai, the most important gold mineralisation known in the Guiana Shield, is an example of an intrusive-hosted deposit, which formed in a calcalkaline stock that intruded backarc/islandarc sequences (Dardenne \& Schobbenhaus, 2003 and references therein).

Dorlin and El Callao/Las Cristinas are well-known examples of volcanic hosted deposits. The Choco 10 deposit in the El Callao gold mining district is situated in greenschist-metamorphic tholeiitic rocks and more heterogeneous volcaniclastic rocks 


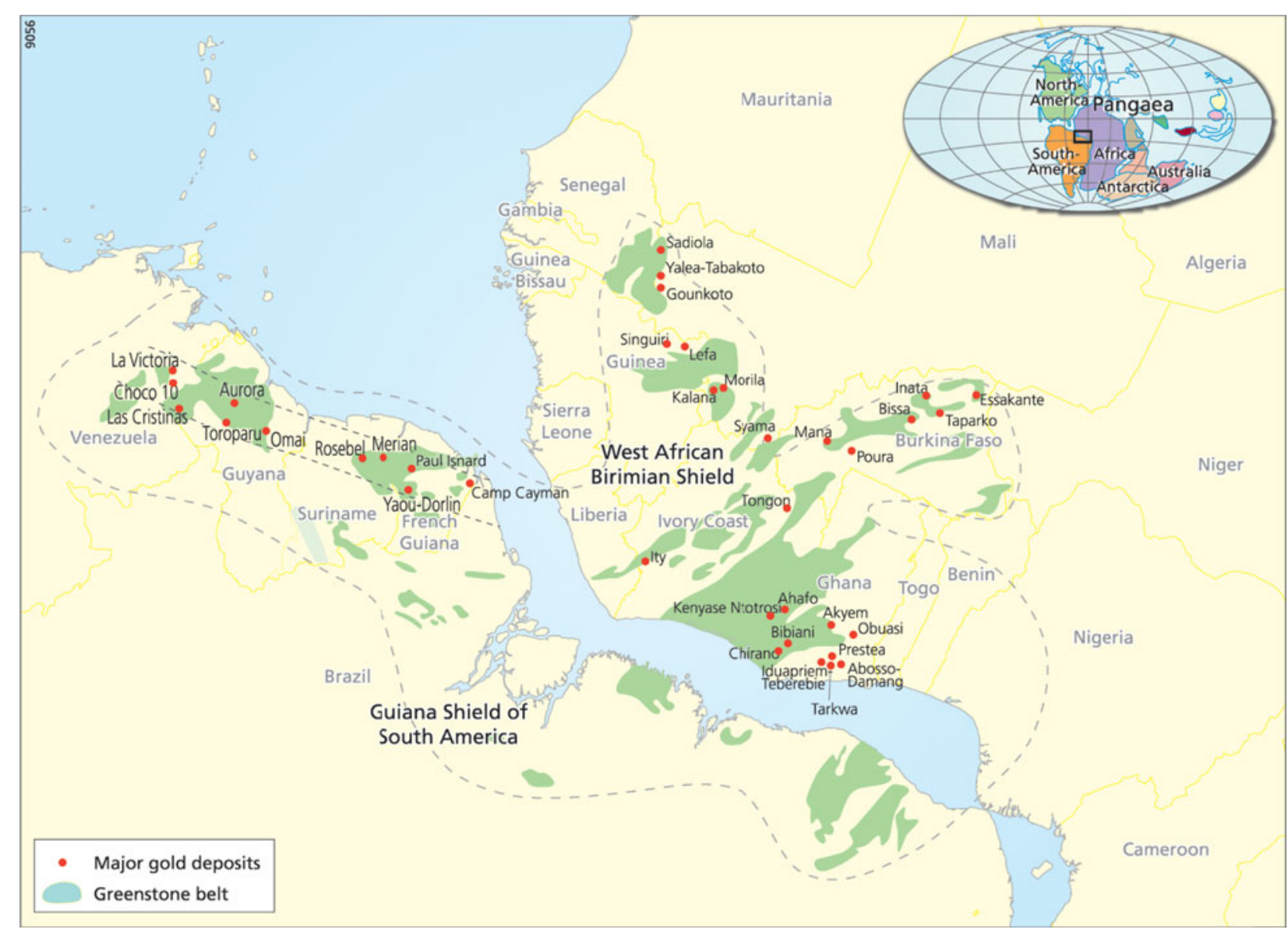

Fig. 20. The major gold deposits in the greenstone belts of the Guiana Shield of South America and the West African Birimian Shield (modified after SRK Consulting (U.S.), Inc., unpublished report, 2015).

with calcalkaline affinity (Padoan et al., 2014). The Dorlin occurrence is hosted by dacitic and volcaniclastic rocks of the Paramaca Group, where the gold is associated with chert and different hydrothermal mineralisations, including one that produced a stratiform tourmaline-bearing deposit (Lerouge et al., 1999). The Camp Caiman deposit is hosted in turbiditic sedimentary sequences of the Armina Formation, largely similar to Rosebel and Merian. In Brazil, the Amapari deposit is hosted in BIFs, and the Santa Maria deposit in metaconglomerate and other coarse metasediments (Dardenne \& Schobbenhaus, 2003 and references therein).

Texeira et al. (2007) fitted the metallogenic events in South America into Wilson cycles involving the assembly and break-up of supercontinents. In this scheme, most mineralisations in the Guiana Shield occurred in a period of rapid crustal growth during the formation of the Atlantica palaeocontinent. Following the onset of subduction in an oceanic environment at c.2.2 Ga, gold mineralisation accompanied ocean closure and orogenesis at c.2.1-2.0 Ga. This sequence of events affected not only the Guiana Shield but also the adjacent Amazon and São Francisco cratons. Involvement of the West-African Birimian Shield, transatlantic mirror of the Guiana Shield (Fig. 20), in the same collision event, resulted in a comparable geological evolution, which explains why this region is renowned for abundant gold mineralisations of similar nature. Major mining operations are Tarkwa, Chirana, Ahato and Obuasi in Ghana, and Tongon in Ivory Coast. Milési et al. (2003) explored correspondences in gold deposition during different stages of magmatic and tectonic accretion during the Palaeoproterozoic evolution of the provinces in French Guiana and West Africa. A most prominent analogy is that in both cases late-stage (from c.2.1 Ga onwards) transcurrent tectonics controlled a wide variety of syntectonic gold-bearing-conglomerate and mesothermal-orogenic deposits, the latter type being the most common. Feybesse et al. (2006) attributed metallogenesis in the Ghanaian world-class gold province, a subprovince of the West African Palaeoproterozoic, to the combination of a continental margin, juvenile magmatism and convergence and collision between an old continent and a juvenile crust.

\section{Concluding remarks}

There is a long history of gold production in Suriname, which in recent years has culminated in the development of major mining operations. Although geological research into the origin and 
setting of gold mineralisation in the country has made considerable progress, many areas remain virtually untouched in terms of modern scientific exploration. The apparent diversity of primary and secondary deposits in the greenstone belt calls for an expansion of research efforts, preferably in a regional context, to better understand the local complexity of gold-producing processes and the geological controls of ore formation in the Guiana Shield in general.

\section{Acknowledgments}

The authors would like to thank Ramon Finkie, Glenn Gemerts, Dennis LaPoint, Sytze Miedema and Shamir Sheikkariem for sharing helpful information, and Ton Markus and Eriaan Wirosono for preparing the drawings. The manuscript benefited from insightful reviews by Dennis LaPoint and Sytze Miedema.

\section{References}

Aleva, G.J.J. \& Wong, Th. E., 1998. History of bauxite exploration and mining in Suriname. In: Wong, Th.E., de Vletter, D., Krook, L., Zonneveld, J. \& van Loon, A., (eds): The history of earth sciences in Suriname. Royal Netherlands Academy of Arts and Sciences \& Netherlands Institute of Applied Geoscience (Amsterdam): 275-310.

Bosma, W., Kroonenberg, S.B., van Lissa, R.V., Maas, K. \& De Roever, E.W.F., 1977. Geological map of Suriname (coloured), scale 1:500,000. Geologische Mijnbouwkundige Dienst Suriname (Paramaribo): 2 sheets.

Bosma, W., Kroonenberg, S.B., van Lissa, R., Maas, K. \& de Roever, E.W.F. 1984. An explanation to the geology of Suriname. Mededelingen Geologisch Mijnbouwkundige Dienst van Suriname 27: 31-82.

Brinck, J.W., 1955. Goudafzettingen in Suriname (Gold deposits in Suriname). $\mathrm{PhD}$ Thesis. University of Leiden (Leiden). Leidse Geologische Mededelingen, deel XXI: 1-246.

Capps, R.C., 2004. Bedrock sources of placer gold-mercury at the Witlage Creek prospect, Eastern Suriname, South America. Poster for Northeastern Section (39th Annual) and SoutheasternSection (53rd Annual) Joint Meeting (March 25-27, 2004). Paper no. 9-1. Geological Society of America Abstracts with Programs 36(2): 43.

Capps, R.C., Moye, R.J., LaPoint, D.J., Watson, T.C., Christensen, D., Stollenwerk, M. \& Cherrywell, C., 2004. Evidence for syntectonic gold mineralization at Gowtu Bergi, Eastern Suriname, South America. Geological Society of America Abstracts with Programs 36(2): 43.

Centrale Bank van Suriname, 2014a. Jaarverslag 2014. Centrale Bank van Suriname (Paramaribo): 67 pp.

Centrale Bank van Suriname, 2014b. Leading sectors of Suriname: the impact of mining, agriculture and tourism activities on the economy 1970-2012. Centrale Bank van Suriname (Paramaribo): 135 pp.

Dahlberg, E.H., 1984. Small-scale gold mining. A manual based on experience in Suriname. Intermediate Technology Development Group (London): 51 pp.

Daoust, C., 2016. Caractérisation stratigraphique, structurale et géochimique du district minéralisé de Rosebel (Suriname) dans le Cadre de l'évolution géodynamique de Bouclier Guyanais. PhD Thesis. Université du Québec à Montréal (Montréal): 330 pp.

Daoust, C., Voicu, G., Brisson, H. \& Gauthier, M., 2011. Geological setting of the Paleoproterozoic Rosebel gold district, Guiana Shield, Suriname. Journal of South American Earth Sciences 32: 222-245.

Dardenne, M.A. \& Schobbenhaus, C., 2003. Metallogeny of the Guiana Shield. Géologie de la France 2-4: 291-319.

Delor, C., de Roever, E.W., Lafon, J.-M, Lahondère, D., Rossi, P., Cocherie, A. \& Potrel, A., 2003. The Bakhuis ultra-high temperature granulite belt (Suriname): II. Implications for the late Transamazonian crustal stretching in a revised Guiana Shield framework. Géologie de la France 2-4: 207-230.

De Vletter, D.R., 1984a. Synthesis of the Precambrian of Suriname and review of some outstanding problems. In: De Vletter, D.R. (ed.): Geology of Suriname 8. Mededelingen Geologisch Mijnbouwkundige Dienst Suriname 27: 11-30.

De Vletter, D.R., 1984b. Economic geology and mineral potential of Suriname. In: De Vletter, D.R. (ed.): Geology of Suriname 8. Mededelingen Geologische Mijnbouwkundige Dienst Suriname 27: 91-129.

De Vletter, D. \& Hakstege, A.L., 1998. The search for gold in Suriname. In: Wong, Th.E, de Vletter, D., Krook, L., Zonneveld, J. \& van Loon, A. (eds): The history of earth sciences in Suriname. Royal Netherlands Academy of Arts and Sciences \& Netherlands Institute of Applied Geoscience (Amsterdam): 311-350.

De Vletter, D., Aleva, G.J.J. \& Kroonenberg, S.B., 1998. Research into the Precambrian of Suriname. In: Wong, Th.E., de Vletter, D., Krook, L., Zonneveld, J. \& van Loon, A. (eds). The history of earth sciences in Suriname. Royal Netherlands Academy of Arts and Sciences \& Netherlands Institute of Applied Geoscience (Amsterdam): 15-64.

Feybesse, J.-L, Billa, M., Guerrot, C., Duguey, E., Lescuyer, J.-L., Milési, J.-P. \& Bouchot, V., 2006. The Paleoproterozoic Ghanaian province: geodynamic model and ore controls, including regional stress modeling. Precambrian Research 149: 149-196.

Gemerts, G., 2015. De mijnbouw in Suriname: verleden, heden en toekomst. In: Verbonden 150 jaar dienstbaar zichtbaar en aan de Surinaamse betrokken samenleving (150 jaar DSB): 65-87.

Gibbs, A.K. \& Barron, C.N., 1993. The geology of the Guiana Shield. Oxford University Press (0xford): $246 \mathrm{pp}$.

Grassalco, N.V., 2016. www.grassalco.com, last accessed on 15 February 2016.

Heemskerk, M., 2009. Kleinschalige goudwinning in Suriname. Een overzicht van sociaaleconomische politieke, en milieu-aspecten. Centrum voor Studie en Documentatie van Latijns Amerika (CEDLA) (Amsterdam) : $41 \mathrm{pp}$.

Iamgold Corporation, 2014. Annual Report 2014. Iamgold Corporation (Toronto): $90 \mathrm{pp}$.

Kroonenberg, S.B., de Roever, E.W.F., Fraga, L.M., Reis, N.J., Faraco, T., Lafon, J.-M., Cordani, U. \& Wong, T.E., 2016. Palaeoproterozoic evolution of the Guiana Shield in Suriname: a revised model. Netherlands Journal of Geosciences. doi: 10.1017/njg.2016.10.

Lerouge, C., Milési, J.-P. \& Fouillac, A.-M., 1999. The Paleoproterozoic Dorlin gold deposit, French Guiana: genetic constraints of the stable isotope geochemistry. Chemical Geology 155(1-2): 131-149.

Milési, J.-P, Ledru, P., Feybesse, J.-L., Dommanget, A. \& Marcoux, E., 1992. Early Proterozoic ore deposits and tectonics of the Birimian orogenic belt, West Africa. Precambrian Research 58: 305-344. 
Milési, J., LeRouge, C., Delor, C., Ledru, P., Billa, M., Cocherie, A., Egal, E., Fouillac, A., Lahondère, D., Lasserre, J., Marot, A., Martel-Jantin, B., Rossi, P., Tegyey, M., Théveniaut, H., Théveniaut, H., Thiéblemont, D. \& Vanderhaege, 0., 2003. Gold deposits (gold-bearing tourmalinities, goldbearing conglomerates, and mesothermal lodes), markers of the geological evolution of French Guiana: geology, metallogeny, and stable-isotope constraints. Géologie de la France 2-4: 257-290.

Naipaul, R. \& Kroonenberg, S.B., 2016. Provenance signals in metaturbidites of the Palaeoproterozoic greenstone belt of the Guiana Shield in Suriname. Netherlands Journal of Geosciences (this issue).

Newmont Mining Corporation, 2014. Fact sheet - Merian. Newmont Mining Corporation (Greenwood Village, C0): $2 \mathrm{pp}$.
Padoan, M., Rossetti, P. \& Rubatto, D., 2014. The Choco 10 gold deposit (El Callao, Bolivar State, Venezuela): petrography, geochemistry and U-Pb geochronology. Precambrian Research 252: 22-38.

Patadien, R.S., 2013. A study of the lithofacies and structural features at the Sabajo Hills area, District of Para. Bachelor Thesis. Anton de Kom University of Suriname (Paramaribo): $80 \mathrm{pp}$.

Teixeira, J.B.G., Misi, A. \& da Glória da Silva, M., 2007. Supercontinent evolution and the Proterozoic metallogeny of South America. Gondwana Research 11: 346-361.

Voicu, G., Bardoux, M. \& Stevenson, R., 2001. Lithostratigraphy, geochronology and gold metallogeny in the northern Guiana Shield, South America: a review. Ore Geology Reviews 18: 211-236. 